This is not a peer-reviewed article.

7th World Congress on Computers in Agriculture and Natural Resources

Conference Proceedings 22-24 June 2009 (Reno, Nevada USA)

Publication Date 22 June 2009

ASABE Publication Number 701P0409e Eds F.S. Zazueta and J. Xin

\title{
Low Cost Technology Applied to Thermometry of Grains
} Marcelo Ferrasa ${ }^{1}$, Marco Antonio Martin Biaggioni ${ }^{2}$, Marcelo Giovaneti Canteri ${ }^{3}$

${ }^{1}$ Universidade Estadual de Ponta Grossa, Av. Carlos Cavalcanti, 4748, CEP: 84030-900, Ponta Grossa, PR, Brazil. ${ }^{2}$ Universidade Estadual Paulista, Rua José Barbosa de Barros, 1780, CEP:18610-307, Botucatu, SP, Brazil. ${ }^{3}$ Universidade Estadual de Londrina, Cx. Postal 6001, CEP: 86051-980, Londrina, PR, Brazil.

Abstract. Modern agriculture demands investments in technology that allows the farmers to improve productivity and quality of their products, aiming to establish themselves in a competitive market. However, the high costs of acquiring and maintaining such technology may be an inhibiting factor to its spread and acceptance, mainly to a large number of small grain Brazilian farmers, who need low cost innovative technological solutions, suitable for their financial reality. Starting from this premise, this paper presents the development of a low cost prototype for monitoring the temperature and humidity of grains stored in silos, and the economic implications of cost/benefit ratio of innovative applications of low cost technology in the process of thermometry of grains. The prototype was made of two electronic units, one for acquisition and another one for data reception, as well as software, which offered the farmers more precise information for the control of aeration. The data communication between the electronic units and the software was reliable and both were developed using low cost electronic components and free software tools. The developed system was considered as potentially viable to small grain Brazilian farmers; it can be used in any type of small silos. It provided reduction of costs of installation and maintenance and also offered an easy expansion system; besides the low cost of development when compared to similar products available in the Brazilian market.

Keywords. small farmers, electronic, software, silo.

\section{Introduction}

The accessibility to financial resources for Brazilian great producers of grains is directly proportional to the investment in technological solutions. However, that relation does not occur with small producers of grains. In this sense it is strategic to turn the technology accessible to the small producers, using acquisition and maintenance low cost technological solutions, to improve the productivity, rationalize energy and to minimize the inherent risks to the agricultural activity.

Molin (2002) explain that there is a repressed demand of agricultural equipment in the country, because their high aggregated values. That occurs due to the production scale lack. So, if the technology evolves and the techniques adapt to the producer's reality, that insertion can occur naturally.

The use of technological solutions in agriculture is important since the planting and beyond the grains harvest. The technology has been contributing to improve the preservation of grains quality. The technology also can offer to the small producer some way to monitor and to control the environmental inside grains silos. Using an effective control, the grains can be stored for a long time keeping acceptable quality for consumption, giving larger autonomy to the small producer for the commercialization.

The present article describes about a technological option of low cost that assists the small producer in monitoring grains storage in silos. It was developed a prototype of a thermometry system, composite by electronic units of data acquisition, transmission and reception and software for processing.

\section{The grain behavior in the storage environment}

Some factors interfere in the quality of the stored grains as: the grains mass temperature, grains humidity content, relative humidity of the air, chemical composition, mechanical damages, impurity, insects and fungi.

Tropical and subtropical regions present temperature and relative humidity not favorable to the grains storage. After the harvest it is necessary to reduce the water content in the grains, using the grains drying process (CARNEIRO, 2003).

Devilla et al. (2004) recommended the grains drying and cleaning before storage. These procedures decrease the micro flora action in the grains mass, retarding the speed of the gaseous changes and the process of natural deterioration. 


\section{Thermometry}

Thermometry is the assessment of temperature of a grain mass stored in silos or grain warehouses, equipped with devices, using thermoelectric pairs. The temperature readings are made in different heights inside the grain mass, with exactness and quickness (PUZZI, 2000).

The thermometry systems installed in the storage silos allow to know and to evaluate the temperature variation (WEBER, 2001). The daily accompaniment of the temperatures allows activate cooling ventilation, in a preventive form, before the temperature reaches value next to the risk of loss for the stored products.

\section{Information Technology and communication in the Brazilian agribusiness}

The set of technological tools has been propitiating increase in the quality level for almost all the stages of the agricultural productive chain, since prepare of the seeds, until the logistics for product transportation.

Fleischfresser (1998) cites that despite all importance reached by the Information and Communication Technologies (ITs), when used in agribusiness, still they restrict to the big companies of the agricultural sector and to the great rural producers. When ITs are used by the small producer, it enables them to improve their activities and increase its competitiveness in the agricultural market. However, this black box of the recent technological tools applied to the agricultural, still can generate doubts and/or fears by the simple unknowingness, or difficulties to access up-to-date information, or low investment capacity, or yet, because cultural barriers.

On the other hand, the researchers and the precision agriculture industry, as well the information managers should find ways to disseminate ITs use, making them of better comprehension and of smaller cost, aiming reach a farmers' larger sample, mostly the ones that do not have access to capital (FLEISCHFRESSER, 1998).

Acording Saraiva (2003), the operations of post-harvest also had been used automation and control systems. An example refers to the drying and storage of products. The control of humidity and temperature of storage grains is a basic operation performed by systems that can automatically transport and to dry the products inside silos or warehouses.

The wireless communication also can reduce the costs of equipments used in the agricultural environment. According to Rebelato and Lidak (2006) that kind of communication can be used to modify the data reading, enabling costs reduction in acquisition and infrastructure maintenance and installation.

\section{Material e Methods}

The prototype of the developed system was divided into three parts: Electronic unit of data acquisition and transmission, electronic unit of data reception and the monitoring software. The electronic unit of data reception was coupled to a computer. The electronic unit of data acquisition and transmission was coupled to the temperature sensors and it was able to transfer the data to the electronic unit of data reception. The computer worked to store and to process the data using a computational program, developed in programming language Java with database MySQL. Both the electronic units used radiofrequency transmitters and receivers for data communication.

The electronic components, the programming language and the database manager, were chosen regarding the goal of develop a functional and low cost prototype.

- Electronic unit of data acquisition and transmission: Temperature sensor LM35, multiplex CD4051B, microcontroller PIC 16F877, transmitter RF RT4 of $433 \mathrm{MHz}$, data codifier MC145026 and CI MAX232, cables UTP type 5 and connectors RJ45 (male and female) for sensors connection, $17 \mathrm{~cm}$ of cable coaxial RG-58 for antenna;

- Electronic unit of data Reception: Receiver RF RR3 of $433 \mathrm{MHz}$, data decoder MC145027, microcontroller PIC 16F877M and 17cm of cable coaxial RG-58 for antenna.

Other components used in the units were tension regulators LM7805 and LM78L12, ceramic and electrolytic capacitors, $1 / 4$ watt resistors, $4 \mathrm{MHz}$ crystals, several leds and transistor LM7812.

The free software MPLAB IDE and EAGLE Light Edition were used for microcontroller programming and to elaborate the electronic units. The NETBEANS IDE was used in the codification process of the computational program in language Java and during creation of the graphic interface and database manipulation MySQL.

The minimum configuration of computer necessary to run the computational program is a 32 bits processor, $500 \mathrm{MHz}$ speed, $64 \mathrm{Mb}$ memory RAM, 20Gb of hard disk, operating system Windows $98{ }^{\circledR}$ or higher with RS-232 serial interface.

The electronic unit of data acquisition and transmission was installed in an experimental silo in the Drying and Storage Laboratory of FCA-UNESP, Botucatu, SP, Brazil. 
Installation outline of the prototype in the experimental silo

The temperature sensors installation was willing along the silo in horizontal layers. They were installed inside the silo in 3 layers, besides the sensor located under the floor (plenum), where it circulates the aeration. The installation performed in the experimental silo is shown in Figures 2 and 3.

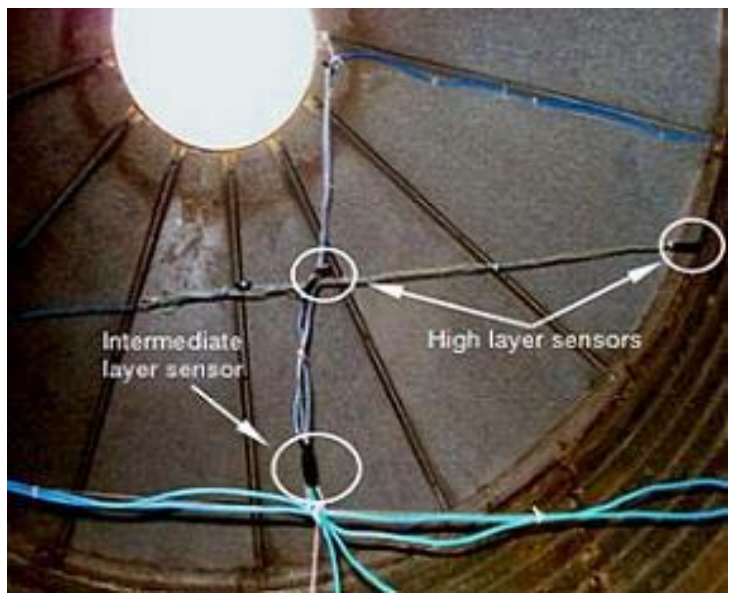

Figure 2. Sensors inside the experimental silo - higher and intemediate layer.

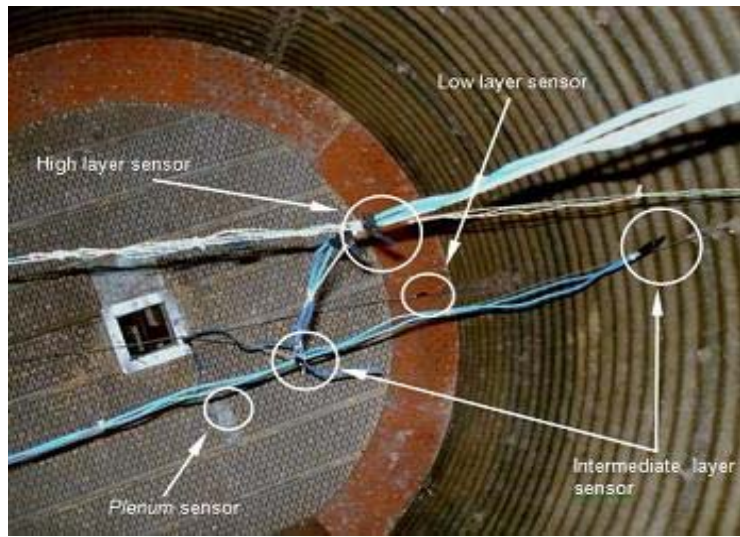

Figure 3. Sensors inside the experimental silo - lower and intermediate layer and plenum.

Twelve temperature sensors were installed, being necessary 2 cables type UTP with eight wires. Every temperature sensor LM35 needed three cables for connection with the electronic unit of data acquisition, and the cable of energy supply to all the sensors was also connected. Therefore, there was connection of six temperature sensors for each UTP cable.

\section{Results}

The circuits and electronic components that compose the data transmission and reception unit were implemented over a proto-board. That device provides flexibility in the addition of electronic components and facilitates the contacts among them. The tests of the electronic units were performed in this phase, due to the fittings and alterations easiness in the project.

Two kinds of tests were performed. The first one checked the communication reliability via radio. A same number sequence was sent, without the presence of sensors, and its reception was checked. The second one tested the range of transmission via radio, with the electronic unit of transmission and the sensors 
installed in the silo. The prototypes of the electronic units in experimental phase are presented in the Figures 4 and 5.

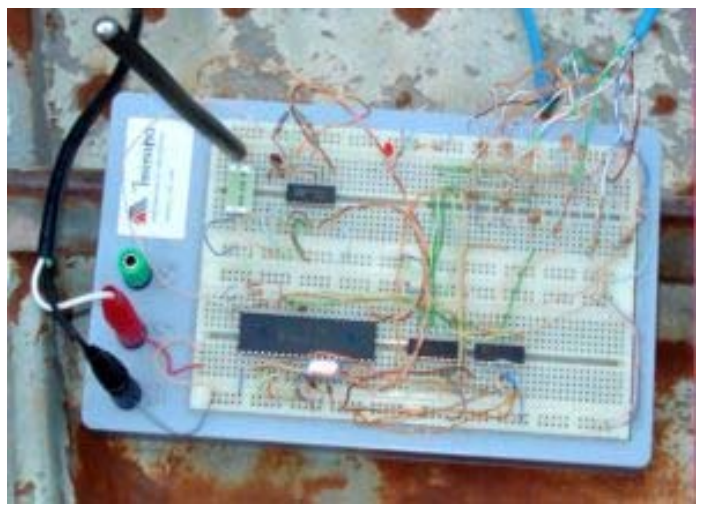

Figure 4. Prototype of eletronic unit of data acquisition and data transmission.

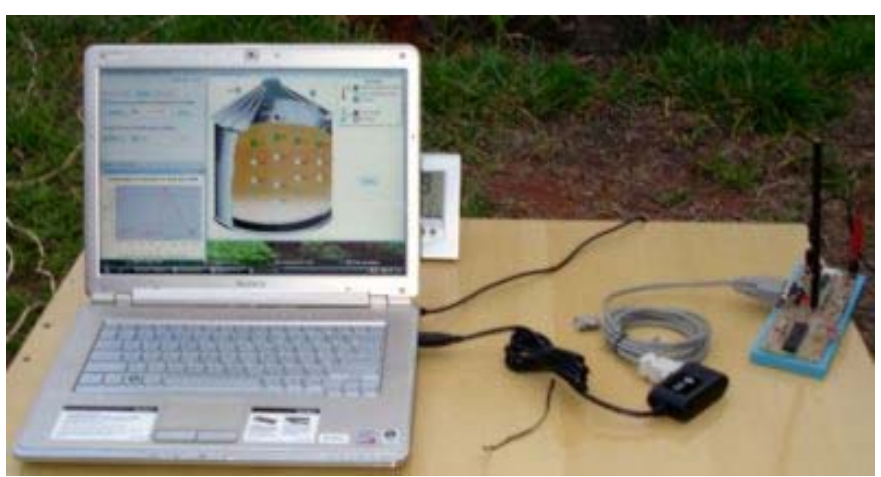

Figura 5. Prototype of electronic unit of data reception using the thermometry software.

The transmission unit coupled to the sensors was installed in the silo and the reception unit was coupled to a computer, being placed at increased distances of 1 meter. The range test was made in distances from 1 to 30 meters. Every sample was made during 10 minutes, always transmitting a fixed number of data.

The tests verified that the communication via radio using a low cost transmitter and receiver it was reliable and absent of errors, inside a distance from 1 to 15 meters. In higher distances, the number of errors grew proportionally to the distance increase. When the range of radio transmission was 30 meters, there was $36.4 \%$ of errors in data transmitted. When 1774 characters were sent, just 1110 characters were received, what affect the communication reliability. Such verification does not correspond to the manufacturer's affirmation that the transmission/reception unit operates in distances from 20 to 30 meters. The maximum distance obtained for a reliable communication belonged to 15 meters.

\section{The prototype cost}

Three important aspects characterize the system as technological product of low cost. First, the low investments in electronic components used in the prototype construction; Second, the communication via radio (using low cost transmission/reception, besides the economy in the cables and infrastructure acquisition); and finally, the free software used for development of the computational program. Such aspects characterize that the prototype fits to the small producers in an economic and social context.

The cost of prototype development embraced the acquisition costs of electronic components and the workmanship cost for the development of the computational program and of the electronic units. Table 1 and 2 present the values. 
Table 1. Workmanship cost for prototype development

\begin{tabular}{|crcc|}
\hline Workmanship* & N $^{\circ}$ hours & Value per hour (U\$) & Total (U\$) \\
\hline Software & 80 & 6.50 & 520.00 \\
Electronic units & 180 & 3.80 & 684.00 \\
Total (1) & & & $\mathbf{1 , 2 0 4 . 0 0}$ \\
\hline
\end{tabular}

*Brazil base: U\$ $1.00=\mathrm{R} \$ 2.11$.

Table 2. Cost of the electronic components and tools used in the prototype development.

\begin{tabular}{|lcrr|}
\hline Components description & Number & Unitary cost (U\$) & Total (U\$)* \\
\hline Temperature sensor LM35 & 32 & 1.80 & 57.60 \\
IC Microcontroller PIC 16F877 & 02 & 7.50 & 15.00 \\
IC Multiplex CD4051B & 04 & 0.30 & 1.20 \\
IC MAX232 & 01 & 0.80 & 0.80 \\
Electrolytic Capacitor & 04 & 0.04 & 0.16 \\
Ceramic Capacitor & 09 & 0.04 & 0.36 \\
Connector RS232 09 pins male & 01 & 0.52 & 0.52 \\
LED 3mm red and blue & 10 & 0.23 & 2.30 \\
Resistors & 60 & 0.004 & 0.24 \\
Connector RJ-45 female (board) & 06 & 0.38 & 2.28 \\
Connector RJ-45 male (cable) & 06 & 1.37 & 8.22 \\
Socket p/ CI 40 pins printed & 02 & 0.20 & 0.40 \\
Cristal 4.0 MHz & 01 & 0.30 & 0.30 \\
Transistor BC547 & 01 & 0.10 & 0.10 \\
Tension regulator LM7812 & 01 & 0.60 & 0.60 \\
Tension regulator LM7805 & 02 & 0.40 & 0.80 \\
Transmission/Reception RF Telecontolli RT4/RR3 & 01 & 20.00 & 20.00 \\
Source 12Vcc 4.6 A & 01 & 20.00 & 20.00 \\
Cable UTP (sensor installation) & 48 & 0.60 & 28.80 \\
Board assembling & 01 & 15.00 & 15.00 \\
& & & $\mathbf{1 7 4 . 6 8}$ \\
\hline
\end{tabular}

*Brazil base: U\$ $1.00=\mathrm{R} \$ 2.11$.

The total cost of development of one prototype formed by the sum of Total (1) and Total (2) was about U\$ 1,378.68. Note that the workmanship value (U\$ 1,204.00) was significant in the composition of the final value, corresponding to $87.3 \%$ of the total. Of this amount, the labor cost to develop the electronic units was U\$ 684.00 , or $56.8 \%$ of the total workmanship cost. The investment in electronic components was U\$ 174.68 , or $12.6 \%$ of the total cost. Inside this percentage the biggest value was the sensors cost, that corresponded to $32.9 \%$ of electronic components.

There are equipment technologically sophisticated with temperature control, aeration and grains mixer management. The cost of such equipment varies of U\$ 3,800.00 to U\$ 5,700.00, relatively high prices to the small producer. Other products of more accessible cost make the temperature monitoring. This product cost U\$ 950.00 but just reads the temperature of every sensor and there is any possibility of remote readings.

The prototype of monitoring system developed in this work offers other advantages as: the comfort of the remote reading without need to displacement; the possibility to visualize the temperature behavior for every sensor; automatic warning when the grains mass temperature hit a critical value; wireless communication. As seen, the development cost of the prototype of monitoring system was around U\$ 1,380.00.It denotes potential reduction of costs production in industrial scale.

\section{Conclusion}

It was possible to develop a product based on low cost technologies for grains thermometry, with potential for implementation for Brazilian small producers.

The low cost wireless communication applied in the grains thermometry, also contributed to minimize installation and maintenance costs.

The development of technologies of low cost for thermometry of grains constitutes a viable opportunity for technological dissemination for small rural properties. 


\section{References}

CARNEIRO, L. M. T. A. Antecipação da colheita, secagem e armazenagem na manutenção da qualidade de grãos e sementes de trigo comum e duro. Tese de doutorado. Universidade Estadual de Campinas. Faculdade de Engenharia Agrícola. Campinas, 2003. 109 p.

DEVILLA, I. A., COUTO, S. M., ZOLNIER, S. Variação da temperatura e umidade de grãos armazenados em silos com aeração. Revista brasileira de engenharia agrícola e ambiental. maio/dez. 2004, vol.8, no.2-3, p.284-291. Disponível em: $<$ http://www.scielo.br/scielo.php?script=sci_arttext\&pid=S141543662004000200018\&ln $g=p t \& n r m=i s o>$. ISSN 1415-4366. Acesso em 15 Out. 2006.

FLEISCHFRESSER, V. Modernização Tecnológica da Agricultura - contrastes regionais e diferenciação social no Paraná da década de 70. Curitiba: CONCITEC/IPARDES, 1988.

MOLIN, J. P. Fatores restritivos à adoção da agricultura de precisão; II Congresso Brasileiro de Soja; 2002. 221-229. Foz do Iguaçu; BRASIL; Português; 1516-781X

PUZZI, D. Abastecimento e armazenamento de grãos. Campinas, SP. ICEA. Edição 2000.

REBELATO, M. G. e LIDAK, G. A transmissão de dados sem fio aplicada à coleta de dados no chão-defábrica. XXVI ENEGEP - ABEPRO 1. p, 1-8. Fortaleza, 2006.

SARAIVA, A. M. TI no Agronegócio e Biodiversidade. In: Práticas de Eletricidade e Eletrônica II. Escola Politécnica da USP. Departamento de Engenharia de Computação e Sistemas Digitais. São Paulo, 2003. $42 p$.

WEBER, E. A. Armazenagem Agrícola, Kepler Weber Industrial. 2ª Ed. Porto Alegre, 2001. 